\title{
O RECEPCJI TWÓRCZOŚCI GEORGA TRAKLA W POEZJI CZESKIEJ
}

\author{
RADEK MALÝ1 \\ (Ołomuniec) \\ Słowa kluczowe: ekspresjonizm, poetyzm, czeska poezja 1928-1938, \\ problematyka niemiecko-czeskiego przekładu, poezja Georga Trakla, poezja Františka Halasa, \\ „poezja jesieni i śmierci“
}

Keywords: expressionism, Czech poetry 1928-1938, problems of Czech-German translation, Georg Trakl's poetry, František Halas' poetry, "the poetry of autumn and death"

\begin{abstract}
Abstrakt: Radek Malý, O RECEPCJI TWÓRCZOŚCI GEORGA TRAKLA W POEZJI CZESKIEJ. „PORÓWNANIA" 10, 2011, Vol. X, ss. 161-172. ISSN1733-165X. Autor tekstu bada związki pomiędzy poezją austriackiego poety Georga Trakla (1887-1914), przedstawiciela ekspresjonizmu, a czeską literaturą - przede wszystkim poezją. Twórczość Trakla miała wpływ na rozwój współczesnej poezji czeskiej za pośrednictwem tłumaczeń Bohuslava Reynka. Poezja czeska lat trzydziestych dwudziestego wieku stała pod znakiem pesymizmu. Motywami przewodnimi były śmierć, rozkład, niepokój, spustoszenie i strach. Jedną z przyczyn powstania takiej atmosfery było tłumaczenie na język czeski poezji Georga Trakla, która następnie popularyzowana była przez Františka Halasa. Konkretne, wyraźne przejawy jego wpływów można znaleźć już w twórczości Bohuslava Reynka, przede wszystkim jednak pojawiają się one w dwóch tomikach Františka Halasa. Poetyka Trakla pozostawiła również ślad w twórczości Františka Hrubína, Viléma Závady i Jana Zahradníčka, u każdego z nich w różnym stopniu. W latach sześćdziesiątych echa twórczości Trakla można odnaleźć przede wszystkim w poezji Zbyňka Hejdy.
\end{abstract}

\begin{abstract}
Radek Malý, ON THE RECEPTION OF GEORG TRAKL'S WORK IN CZECH POETRY. „PORÓWNANIA” 10, 2011, Vol. X, pp. 161-172. ISSN1733-165X. The author of the study examines the relation between the poetry of the Austrian expressionist Georg Trakl (1887-1914) and Czech literature, especially poetry. Trakl's work in translations by Bohuslav Reynek has affected the development of the modern Czech poetry. The thirties of the twentieth century in the Czech poetry are marked by pessimism, motifs of death, decay, frustration and fear. Trakl's poetry translated into Czech was a contributory cause of this atmosphere. We can already find specific and significant manifestations of its influence in the work of Bohuslav Reynek, and in
\end{abstract}

${ }^{1}$ E-mail Address: radek.maly@upol.cz 
the first two collections of František Halas. In varying degrees, they have left traces in the poetry of František Hrubín, Vilém Závada and Jan Zahradníček. The echoes of Trakl's poetry can also be read in the sixties by poet Zbyněk Hejda.

Austriacki poeta Georg Trakl, przedstawiciel ekspresjonizmu (1887, Salzburg 1914, Kraków), za pośrednictwem swojej poezji pozostawił wyraźny ślad w historii współczesnej literatury powszechnej. Burzliwe koleje jego życia oraz - przede wszystkim - twórczość poetycka zawarta w dwóch niewielkich zbiorach (Gedichte, 1913 oraz Sebastian im Traum, 1915), a także w nieopublikowanej za życia spuściźnie literackiej, niepokoiły i inspirowały już twórców współczesnych poecie. Po drugiej wojnie światowej zainteresowanie poetyckim dorobkiem Georga Trakla wzrosło również wśród badaczy literatury i nie ustaje do dziś.

Od lat dwudziestych dwudziestego wieku twórczość Trakla miała wpływ również na rozwój czeskiej poezji dzięki stosunkowo wczesnym tłumaczeniom dokonanym przez Bohuslava Reynka (1917 oraz 1924), a następnie Ludvíka Kunderę (1965 oraz 1995). W przypadku Reynka było to pierwsze tłumaczenie poezji Trakla na język obcy w ogóle. Należy zadać sobie pytanie, do jakiego stopnia można odnaleźć ślady poezji Trakla w twórczości czeskich autorów oraz w jaki sposób autorzy ci odzwierciedlali w swojej poezji wiersze i specyficzną poetykę Trakla.

$\mathrm{Na}$ początku lat trzydziestych w Czechosłowacji zaczęto wydawać tomiki młodych poetów, którzy reagowali na poprzednią epokę poetyzmu, odznaczającą się niefrasobliwością i optymistycznym podejściem do życia. Dla poetów tych - Františka Halasa, Viléma Závady, Jana Zahradníčka, Vladimíra Holana i innych - istotnymi motywami były jesień, smutek i śmierć. Poprzez tłumaczenia Reynka oddziaływała na nich również twórczość poetycka Georga Trakla. Pojawiają się te same motywy przemijania, ta sama atmosfera lęku, niekiedy nawet dosłowne cytacje.

Poeta, tłumacz i grafik Bohuslav Reynek (1892-1971), podobnie jak liczni młodzi poeci jego generacji, zaczynał publikować w czasopiśmie Moderní revue. Te wczesne wiersze, noszące wpływy zarówno impresjonizmu, jak i symbolizmu, w roku 1914 pojawiły się w sąsiedztwie twórczości takich autorów, jak Jiří Karásek ze Lvovic czy Josef Hora. Bardzo wcześnie, bowiem już w roku 1914, rozpoczęła się znamienna współpraca Reynka z Josefem Florianem - wydawcą z miejscowości Stará Ǩ́íše na pograniczu czesko-morawskim. Florian w swoim wydawnictwie "Dobré dílo" wykorzystywał i rozwijał wszystkie aspekty talentu Reynka - translatorski, poetycki i plastyczny. W wydawnictwie tym wyszły również pierwsze tomiki Reynka o tematyce duchowej: Žízně (1921) oraz Smutek země (1924), w których autor rozwija swój specyficzny, stylizowany na archaiczny styl. 
W roku 1916, w wieku lat dwudziestu czterech, Reynek pisze do współpracownika i przyjaciela Josefa Floriana - A.L. Stř́ǐza:

Pan Florian ma zbiór wierszy G. Trakla, może Pan czytał? Ostatnimi czasy ja również je dostałem i mam zamiar je przetłumaczyć. Poza Francją i Hlaváčkiem nie znam piękniejszych wierszy. Postrzega rzeczy w całkiem nowy sposób, a im bliżej jest końca książki, tym głębiej i szerzej widzi².

List ten jest świadectwem początku długoletniej fascynacji Reynka Traklem. Tłumaczenie pierwszego zbioru poezji Trakla zostało wydane w wydawnictwie „Dobré dílo" pod tytułem Básně Jiř̌ho Trakla już w 1917 roku, a przekład drugiego - pod tytułem Šebastián ve snu - wyszedł siedem lat później, w roku 1924. Fascynacja Reynka Traklem jest zatem początkiem sieci zależności, które łączą wielu czeskich poetów okresu międzywojnia - a także późniejszych generacji - z poezją austriackiego liryka.

Bohuslav Reynek znalazł w Traklu pokrewną duchowość i poezję, która współgrała z jego poetyką. Mroczna, melancholijna poezja Trakla, dla której w czeskim kontekście Reynek odnalazł i wykreował osobliwą ekspresję poetycką, przetarła mu drogę do ekspresjonizmu. Podstawowe założenia tego kierunku, takie jak poczucie zagłady i wyobcowania oraz poszukiwanie dysharmonijnych motywów i środków wyrazu, Bohuslav Reynek w swoich trzech tomikach z lat dwudziestych stworzył jeden z najwyraźniejszych, choć w swoim czasie peryferyjnych, obrazów czeskiego poetyckiego ekspresjonizmu.

Zresztą Trakl nie był jedynym poetą reprezentującym ekspresjonizm, którego twórczość tłumaczył Reynek. Dzięki staraniom Reynka w latach dwudziestych na język czeski zostały przetłumaczone najważniejsze utwory i tomiki poetów, prozaików oraz teoretyków tego nurtu. Czescy czytelnicy za pośrednictwem serii wydawniczej "Nova et Vetera”, którą publikowało wydawnictwo Floriana, mogli zapoznać się z twórczością Theodora Däublera, René Schickelego, Kasimira Edschmida, Georga Heyma czy Elsy Lasker-Schüler. Trakl wszakże zajmuje wśród nich specyficzne miejsce. Już sama jego pozycja, jako Austriaka na obrzeżach obszaru niemieckojęzycznego, jednakże nie w wymuszonej, lecz raczej pożądanej izolacji, w sposób godny uwagi koresponduje $\mathrm{z}$ umiejscowieniem Bohuslava Reynka na czeskiej scenie literackiej. Zarówno Reynek, jak i Trakl nienawidzili miasta, poza tym dla obu charakterystyczne są głębokie korzenie religijne.

Wspólną oś ich twórczości tworzy przede wszystkim przecięcie się dwóch wyjątkowo podobnych "poetyk jesiennych”. Uderzająca jest choćby wspólnota toposu, który jest właściwy dla poezji obu twórców - nieruchoma atmosfera pustych wiej-

2 J. Med, Od snu o ráji k prožitku apokalypsy, w: Bohuslav Reynek (1892-1971). Výstava ke 100. výročí narození. Brno 1992, s. 32. 
skich budynków, motyw opuszczonego ogrodu, ta sama paleta barw. Kolorystyka Trakla, w której - oprócz specyficznego błękitu - przeważają ciepłe barwy jesieni, znajduje odzew w poezji Reynka, przesyconej rdzawym kolorytem rozkładu. Kiedy obaj poeci opisują kolor zielony, nie chodzi im o świeżą wiosenną zieleń, lecz o niezdrową zieleń pleśni. Poezja Reynka współgra z twórczością Trakla przede wszystkim poprzez tragiczne postrzeganie świata. Dlatego też nie należy się dziwić, że u obu poetów znaleźć można takie same lub podobne tytuły poszczególnych wierszy: Zimní večer, Zánik, Procházka na podzim, Tři pisně o srdci, U rybníka, Jitro $v$ zimě, Soumrak itd. Paralele odnaleźć można na poziomie tematyki czy układu motywów, rzadziej na poziomie słów czy cytatów. Rozkład i spustoszenie, które wśród ekspresjonistów są rekwizytami powszechnymi, u Trakla i Reynka przestają być jedynie rekwizytami. Jak zauważył Vojtěch Jirát, u Trakla nie chodzi o wyrażanie "uczucia tragizmu", lecz o bezpośrednie przeżywanie tego uczucia, $\mathrm{o}$ "przeżywanie dekadencji” ${ }^{3}$. Tragiczne wyobrażenia znajdują odzwierciedlenie w fatalnym dążeniu do upadku i przenikają do każdego zakamarka poezji, do każdej metafory. Nawet najpiękniejsze wyrażenia i pojęcia, jak wiosna, anioł czy miłość, postrzegane są przez pryzmat rozkładu i świadomości śmierci.

"Tragiczne postrzeganie" na jakiś czas ogarnia również wyobraźnię Reynka i stanowi inspirację do powstania trzech tomików, które dziś niebezpodstawnie uważane są za szczytowe osiągnięcie czeskiej poezji ekspresjonistycznej - dwa zbiory prozy poetyckiej Rybí šupiny (1922) oraz Had na sněhu (1924), a także tomik wierszy Rty a zuby (1925). Wszystkie powstawały podczas pierwszej wojny światowej, która zarówno dla Trakla, jak i dla Reynka jawiła się jako prawdziwy obraz piekła na ziemi i pobudzała wrażliwego ducha do tworzenia coraz to bardziej okrutnych metafor. Poczucie lęku i grozy, które przepełniało podmiot liryczny w twórczości poety, prowadziło nawet do konwulsyjnej ekspresji - również typowej dla okresu ekspresjonizmu.

Dla ukazania pokrewieństwa łączącego twórczość obu poetów warto przytoczyć trzecią strofę wiersza Trakla pod tytułem Winterdämmerung:

Kirchen, Brücken und Spital

Grauenvoll im Zwielicht stehen.

Blutbefleckte Linnen blähen

Segel sich auf dem Kanal' ${ }^{4}$.

Strofa ta w tłumaczeniu Reynka brzmi następująco:

Chrámy, mosty, nemocnice

v šerosvitu mají hrůzy líce.

3 V. Jirát, Dva předchůdci: Georg Trakl a Georg Heym. „Kritický měsíčník“” 1943, nr 5, s. 147-153.

${ }^{4}$ G. Trakl, Das dichterische Werk. München 1998, s. 14. 
Mnohé prostěradlo krví poskvrněné,

plachtou na průplavu vítr žene ${ }^{5}$.

Taki sam dobór słów oraz poetycka kolorystyka pojawiają się w wierszu Reynka pod tytułem Večer:

Moře... Nemocnice siná,

v které údů běl se vzpíná

nad zteřelá prostěradla ${ }^{6}$.

Spośród obrazów, które Reynek bezpośrednio przejął od Trakla, można wymienić chociażby wyrażenie „černá rosa“ [„czarna rosa”] - rodzaj „metafory absolutnej", która w niemieckiej poezji ma długoletnią tradycję. U Reynka zwrot ten pojawia się w zbiorze Odlet vlaštovek z lat sześćdziesiątych, u Trakla w wierszach Chlapci Elisovi oraz Podzim samotáře.

Wiersze Reynka z tego okresu najbardziej przekonujące są nie tam, gdzie dają się ponieść obrazowości Trakla, lecz w momentach, w których twórczość Trakla była wyłącznie impulsem dla ich obrazowości. Pojawia się oto źródło, które było wprawdzie obecne w czeskiej poezji od wielu stuleci, nigdy jednak nie odegrało zasadniczej roli - tradycyjnie bowiem od czeskiej poezji oczekuje się nastroju radosnego, optymistycznego, tak zwanego „ukrytego imperatywu Bel Canta” (pojęcie Miloslava Topinki) ${ }^{7}$.

O tym, jaki los spotkałby przekłady Trakla autorstwa Reynka, gdyby nie miały tak znaczącego wpływu na młodego poetę Františka Halasa (1901-1949), można tylko spekulować. Pewne jest to, że to właśnie zainteresowanie Halasa, popularyzowanie przez niego twórczości Trakla wśród znajomych z „centralnych” kręgów poetyckich, a także echa poezji Trakla czy Reynka w jego własnej twórczości w pierwszym okresie, który obejmuje wydania tomików Sépie (1927), Kohout plaší smrt (1930) aż do zbioru Dokořán (1936) - odegrało zasadniczą rolę w rozwoju czeskiej poezji okresu międzywojnia.

Wpływ Trakla na wczesną twórczość Františka Halasa jest faktem znanym, potwierdzonym zarówno poprzez świadectwo samego autora czy też jego przyjaciół, jak i badania naukowe - tematem tym zajmowali się na przykład Ludvík Kundera, Jaroslav Med ${ }^{8}$ czy Karel Milota ${ }^{9}$. Jednakże samo stwierdzenie tej zależności nie jest

${ }^{5}$ G. Trakl, Básně Jiřího Trakla. Przeł. B. Reynek. Stará Říše 1917, s. 16. [Tłumaczenie filologiczne w języku polskim: „Kościoły, mosty, szpital / w półmroku mają grozy oblicza. / Niejedno prześcieradło krwią splamione, / żagiel w kanale wiatr gna." (przyp. tłum.)]

${ }^{6}$ B. Reynek, Rty a zuby, w: Básnické spisy. Zlín 1995, s. 295. [Tłumaczenie filologiczne: „Morze... Szpital siny, / w którym członków biel wspina się / nad wytarte prześcieradła" (przyp. tłum.)].

${ }^{7}$ M. Topinka, České bel canto. „Sešity pro mladou literaturu“ 2, 1967, nr 9, s. 154-155.

8 J. Med, Reynkův odlet vlaštovek. "Akord - revue pro literaturu, umění a život" 1990/91, s. 9.

${ }^{9}$ K. Milota, Šebestián proklátý a proklatý. „Literární noviny“ 1997, nr 31, s. 6-7. 
wystarczające - załóżmy, że taki fakt miał miejsce - trzeba jeszcze spróbować tę zależność zdefiniować i wskazać w konkretnych utworach. Należy zaznaczyć, że nie jest to zadanie łatwe, ponieważ Trakl, Reynek i Halas byli indywidualistami i mimo swego młodego wieku (mowa przede wszystkim o ich wczesnej twórczości) dojrzałymi poetami; w twórczości Halasa doszło zatem do zetknięcia się i częściowego przenikania trzech poetyk, trzech podobnych, ale zdecydowanie nietożsamych spojrzeń na świat.

Jako pierwszy dostrzegł tę zależność już w roku 1930 inny przedstawiciel poetyzmu - wybitny czeski poeta Vítězslav Nezval. W jego bardzo negatywnej krytyce drugiego tomiku Halasa Kohout plaší smrt, świadomie wykorzystana została kakofonia oraz motywy śmierci:

Utwory Halasa sprawiają wrażenie marnego tłumaczenia raczej niezłej poezji, która została zepsuta przez nieświadomego i nieudolnego tłumacza bardzo starej daty... Szkoda mi słów na rozprawianie o traklowszczyznach (przede wszystkim w utworach czysto opisowych) i umarlactwach Halasa, aczkolwiek są one obrzydliwe ${ }^{10}$.

We fragmencie tym Nezval nawiązuje do poetyckiego języka Reynka, który rzeczywiście sprawia wrażenie archaicznego i który Halas faktycznie po części przejął. Aby to zrozumieć, wystarczy sięgnąć do juweniliów Halasa. Wpływ Trakla widać już w jego najwcześniejszych rękopisach - i jest to wpływ niewątpliwy, na poziomie cytatu (choć szukanie wyłącznie takich paralel byłoby mylące i ograniczające). Chodzi konkretnie o charakterystyczne wyrażenie „oblé oči” [„obłe oczy"], które zapożyczone zostało z przetłumaczonego przez Reynka sformułowania Trakla "runde Augen” (tłumaczenie dosłowne: okrągłe oczy). Pojawia się on w trzeciej zwrotce utworu Halasa pt. Melancholie (1924) w wersie "vy oblé oči nemohu pro vás spát" [„wy obłe oczy nie mogę dla was spać”].

Oprócz tego cytatu, jak również ulubionego tytułu Trakla (zarówno w twórczości Trakla, jak i Halasa znaleźć można kilka tak zatytułowanych tekstów) w tekście wiersza w kilku miejscach emanuje coś, co można określić mianem "traklowską atmosferę". Wers Halasa "Zapomenutou legendu v tichu úst říkám" w drugiej strofie odsyła do wiersza Trakla Am Mönchsberg zawierającego wers "Leise sagend die vergessene Legende des Walds”, który Reynek tłumaczy jako "potichu říkající zapomenutou legendu lesa" ["po cichu opowiadający zapomnianą legendę lasu"].

Kolejne przykłady znaleźć można w wierszu Halasa datowanym na rok 1929. Jest on częścią listu do przyszłej żony Halasa Libušy Rejlovej:

1. Ve zlatém hvozdu modrý pták krvácí

chlapec tají dech a klopýtá o své slzy

Malý zpěváček vypadlý z hnízda hvězd

10 V. Nezval, Manifesty, eseje a kritické projery z poetismu. Kohout plaši smrt, w: Dílo XXIV. Praha 1967, s. 212. 
2. ...

3. Tehda jeho spravedlivé dny jsou naplněny

a chlapec proměněn $\mathrm{v}$ krystal

stává se trůnem lásky

Jeho něha zní strachem kolouchů a pláče

na nebevzetí jejích ňader se usmívá

a ř́ká jí jménem při němž mlknou ptáci ${ }^{11}$

Pojawia się między innymi pytanie, dlaczego Halas nie włączył tego wiersza do żadnego tomiku. Można by, na prawach odważnej hipotezy, zasugerować następujący powód: pozostaje on zanadto pod wpływem Trakla; chodzi o coś na kształt „wariacji na temat Trakla” w wykonaniu Halasa - konkretnie na temat wiersza An den Knaben Elis oraz Elis z drugiego tomiku Trakla. Podobieństwo utworów Trakla i Halasa, przejawiające się nie na powierzchownym, "finalnym" poziomie, ale gdzieś głębiej w tekstach, musi być oczywiste dla uważnego czytelnika. Można przytoczyć niektóre fragmenty tłumaczeń obu wierszy Reynka pochodzące z tomiku pt. Šebastián ve snu:

Elise, zvolá-li v černém lese kos, tot' tvoje zkáza.

Rty tvé pijí chlad modrého pramene ze skály.

Zanech, krvácí-li potichu tvé čelo, pradávných legend a temného výkladu z drah ptačího letu.

Ty však béřeš se tichými kroky do noci, jež ověšena všecička jest hrozny purpurovými, a krásně rozvíráš náručí v modro.

ֻ̌ Černá jeskyně jest naše mlčení z níž občas vychází sladké zviřre a pomalu klopí těžká víčka. Na tvé spánky kane černá rosa, poslední zlato rozpadlých hvězd.

11 Z dopisu Libuši Rejlové 21. 5. 1929. „Host do domu“ 1967, nr 10, s. 43. [Tłumaczenie filologiczne: „W złotym ostępie błękitny ptak krwawi / chłopiec wstrzymuje oddech i potyka się o swoje łzy / Malutki śpiewak który wypadł z gniazda gwiazd / ... / Wówczas jego sprawiedliwe dni są wypełnione / a chłopiec przemieniony w kryształ / staje się tronem miłości / Jego czułość brzmi strachem jelonków i płacze / do wniebowzięcia jej piersi uśmiecha się / i nazywa ją imieniem przy którym milkną ptaki / ..." (przyp. tłum.)]. 
Dokonalé jest ticho tohoto zlatého dne.

Pod starými duby

ty se, Elise, zjevuješ, odpočívající s oblýma očima.

Modř jejich odráží dřímotu milujících.

Ó! Jak spravedlivi jsou, Elise, všickni tví dnové!

$\cdots$

a zatím hlava jeho klesá do podušek černých

Modrá zvěř

ticha krvácí v houští trnů.

$\cdots$

Znamení a hvězdy

tiše se propadají v soumračném jezeře ${ }^{12}$.

Mamy tutaj do czynienia z bardziej skomplikowaną siecią zależności niż w przypadku poprzedniego wiersza. Trudno w tym miejscu o cytaty, choć i one się pojawiają - charakterystyczne jest np. współbrzmienie wersu Trakla „Ó! Jak spravedlivi jsou, Elise, všickni tví dnové!” [„O! Jakże sprawiedliwe są, Elisie, wszystkie twoje dni!”] oraz Halasa „Tehda jeho spravedlivé dny jsou naplněny” [„,Wówczas dobiegły jego sprawiedliwe dni”]. Bardziej istotna jest jednak wzajemna zgodność strony formalnej - czyli trójwersowe strofy wiersza wolnego. Oczywiste jest również nawiązanie na poziomie leksykalnym - Trakl ma specyficzny słownik, lecz nie zawiera on archaizmów - dodaje je dopiero jego tłumacz Bohuslav Reynek. Dobór słów u Halasa, takich jak "hvozd” ["ostęp”], "tajnosnubný" [„skrytopłciowy”] czy forma „mlknou“ [„milkną”], może mieć swoje źródło właśnie w przekładach Trakla autorstwa Reynka. Wszystkie zapożyczenia są jednak interpretowane w wyrafinowany sposób, są wkomponowane w nowy tekst a mianowicie w wariacje Halasa na temat „elisowskiego" utworu Trakla.

Ten sposób twórczości stał się później dla Halasa typowy - w zbiorach Sépie oraz Kohout plaši smrt można odnaleźć wiele takich przykładów na różnych poziomach tekstu: od doboru słownictwa, poprzez zabiegi składniowe aż do kompozycji wiersza. Przykładem metafory, którą Halas zapożycza i stosuje w zbiorze

${ }_{12}$ G. Trakl, Das dichterische Werk. München 1998, s. 50. [Tłumaczenie filologiczne: „Elisie, gdy woła w czarnym lesie kos, / to twoja zguba. / Wargi twe piją chłód błękitnego źródła ze skały. / Porzuć, gdy krwawi po cichu twoje czoło, / pradawne legendy / i mroczną interpretację ze szlaków ptasiego lotu. / Jednakże ty podążasz cichymi krokami w noc, / która obwieszona jest caluteńka winogronami purpurowymi, / i pięknie rozkładasz ramiona w błękit. / Czarną jaskinią jest nasze milczenie / z której niekiedy wychodzi słodkie zwierzę / i powoli opuszcza ciężkie powieki. / Na twoje sny kapie czarna rosa, / ostatnie złoto po rozpadzie gwiazd. / Doskonała jest cisza tego złotego dnia. / Pod starymi dębami / ty się, Elisie, pojawiasz, odpoczywając, o obłych oczach. / Błękit ich odzwierciedla drzemkę kochanków. / ... / O! Jakże sprawiedliwe są, Elisie, wszystkie twoje dni! / ... / a tymczasem głowa jego opada na poduszki czarne / Błękitna zwierzyna / cicho krwawi w gąszczu cierni. / ... / Znaki i gwiazdy / cicho pogrążają się w zmierzchającym jeziorze.“ (przyp. tłum.)] 
Kohout plaší smrt, jest poetyckie wykorzystanie motywu anioła. U Trakla metafora ta występuje w formie wyrażenia "modré mákové oči anděla" [„,błękitne makowe oczy anioła"], u Halasa natomiast znaleźć można "anděla makového" [„,anioła makowego"]; gdzie indziej u Trakla pojawia się wers „Z šedých pokojů vycházejí andělé s zablácenými křídly" [,Z szarych pokojów wychodzą anioły o zabłoconych skrzydłach”]13, u Halasa zaś „anděl srdce kulhá táhna za sebou špinavé křídlo" [„,anioł serca kuleje ciągnąc za sobą brudne skrzydło"] ${ }^{14}$.

Halasa, tak samo jak Reynka, łączy z Traklem przede wszystkim tragiczne postrzeganie świata. Jest ono u niego obecne również później, jednakże w tomikach $\mathrm{z}$ drugiej połowy lat trzydziestych ostatnie ślady inspiracji Traklem zanikają. Tragiczne postrzeganie świata $\mathrm{w}$ pewnej fazie twórczości jest charakterystyczne dla wszystkich niżej wymienionych poetów, jednak to właśnie u Halasa uzyskuje ono najbardziej autentyczną formę. Mimo iż u wczesnego Halasa można odnaleźć również dosłowne cytaty z Trakla, nie jest to powód, aby traktować te utwory jako „przepisane” czy „mało oryginalne”. Wręcz przeciwnie, Halas uprzedził sposób, w jaki poezja nowoczesna wykorzystuje cytaty. Wszakże nawet Trakl, o czym Halas nie mógł jeszcze wiedzieć, cytuje w swojej poezji Jeana Arthura Rimbauda.

Szukając śladów liryki Trakla w czeskiej poezji lat trzydziestych, należy jeszcze wspomnieć o przynajmniej trzech nazwiskach: Vilém Závada, Jan Zahradníček oraz František Hrubín. Niewielu z nich było tak związanych z ekspresjonizmem jak Halas, wszyscy jednakże należeli do grona przyjaciół Halasa i niewykluczone, że za jego pośrednictwem zaznajomili się z twórczością Trakla.

Tylko u Viléma Závady (1905-1982) można zetknąć się z podobnie intensywnym doznaniem ekspresjonizmu, jakie pojawia się u Reynka i Halasa. Jako jeden z niewielu czeskich poetów Závada naprawdę przeżywał ekspresjonizm, nie koncentrował się jedynie wokół jego zewnętrznych oznak. Mimo podobieństwa poetyk Závady oraz Reynka pojawiają się między innymi istotne różnice: poezja Reynka, ale często także Trakla i Halasa, zmierza do wnętrza, wersy kurczą się w zamknięte, czasem sprawiające wrażenie konwulsyjnych formy, które zdają się być hermetyczne. Dla poezji Závady charakterystyczny jest ruch odśrodkowy oraz dążenie do apelatywności. Z dzisiejszego punktu widzenia jego - oraz Halasa - odejście od poetyzmu, zmierzające $\mathrm{w}$ stronę mrocznej poezji pełnej motywów jesieni, rozkładu i śmierci, traktowane jest jako programowe, jednakże po analizie dokumentów pochodzących z tego okresu można stwierdzić, że odejście to nie było tak jednoznaczne i proste. Każdy z poetów musiał stoczyć wewnętrzną walkę; wszyscy mieli za sobą "przeszłość poetyzmu". Pierwszy tomik Závady dystansuje się już od tego nurtu - rzecz dotyczy zbioru Panychida z roku 1927. Także w dwóch następnych tomikach można odnaleźć podobnie egzaltowane, ekspresywne nacechowanie - w zbiorach pt. Siréna (1932) i Hradní věž (1940).

\footnotetext{
${ }_{13}$ G. Trakl, Šebastian v snu. Przeł. B. Reynek. Vyškov 1924, s. 51.
}

${ }^{14}$ F. Halas, Kohout plaší smrt. Praha 1948, s. 14. 
Ekspresjonizm Viléma Závady bliższy jest Traklowi; wskazują na to konkretne cytaty (takie same tytuły wierszy, lecz również nienaturalne dla języka czeskiego, a bardzo lubiane przez Trakla sformułowanie "vůně rezed" ["zapach rezed”]), środki formalne (aliteracja) czy motywy. Obu twórców łączą dwa motywy, które, choć systematycznie wykorzystywane przez obydwu autorów, nie są przy tym charakterystyczne dla niemieckiego ekspresjonizmu. Chodzi o połączenie erotycznych wyobrażeń ze śmiercią oraz o motyw jesieni wiosną. Jest to $w$ zasadzie kontaminacja przeciwstawnych motywów, które mają swoje źródła w tragicznym postrzeganiu świata - każdy pozytywny element jest przekształcany w swoje przeciwieństwo, nieustannie sugerowana jest obecność zagrożenia zagładą.

Dziś nazwisko Jana Zahradníčka (1905-1960) niebezpodstawnie kojarzone jest ze szczy towymi osiągnięciami czeskiej poezji duchowej i katolickiej. Swoją indywidualną ekspresję poetycką Zahradníček osiągnął dopiero w trzecim tomiku Jeřáby (1933); jego wcześniejsze utwory są próbą uporania się z wpływem Halasa i Závady, a zatem również Trakla. Zahradníček dobrze znał twórczość Trakla - sam nawet przetłumaczył dwa jego wiersze na język czeski. W jego pierwszym tomiku pt. Pokušení smrti (1930) zależność ta przejawia się na tyle wyraźnie, że na pierwszy plan wysuwają się nastroje, które panowały w poezji ówczesnych lat - u Zahradníčka brakuje jednak autentyczności przeżycia, które mogłoby im odpowiadać. Wczesna twórczość Zahradníčka tworzy zatem swoistą granicę wpływu Trakla na czeską poezję - bez wiarygodnego doznania prowadzi wyłącznie do mechanicznego zestawiania beznadziejnych obrazów unicestwienia, smutku oraz żalu nad sobą.

Poezja Zahradníčka jest $\mathrm{w}$ dużej mierze konglomeratem cytatów oraz środków formalnych innych poetów - od Trakla, poprzez Reynka po Halasa. Jako krótki przykład mogą posłużyć dwie strofy utworu Proč:

Hoře rozumu přikrývaje se stíny si šeptám

Podobny do jiného světa otevřeným dveřím

sladké rány kvílejíce purpurově zejí

Vystaven úpěnlivým průvanům překrásně hořím

Ale proč zrána úmyslně oči rozbijím si?

Proč v popelavém úsvitě tolik se podobám své smrti?

Proč nechci se dát ničím utěšiti

a nejvíc miluji to co mne skličuje a drtí? ${ }^{15}$

...

${ }_{15}$ J. Zahradníček, Pokušení smrti, w: Básnické dílo I. Praha 1991, s. 24. [Tłumaczenie filologiczne: „Zgryzotę rozumu przykrywając z cieniami sobie szepczę / Podobne do otwartych do innego świata drzwi / słodkie rany jęcząc purpurowo zieją / Wystawiony na rzewne przeciągi przepięknie płonę / Ale dlaczego rano naumyślnie oczy sobie rozbijam? / Dlaczego popielatym świtem tak bardzo jestem podobny do swojej śmierci? / Dlaczego nie chcę pozwolić żeby mnie coś pocieszyło / a najbardziej kocham to co mnie przygnębia i druzgocze?" (przyp. tłum.)]. 
Zahradníček zamyka tę fazę swojej twórczości już w swoim drugim tomie Návrat (1931), w którym odnajduje tak charakterystyczny dla siebie swoisty wyraz duchowy.

Wpływ poetyki Trakla na czeską poezję w latach trzydziestych był na tyle silny, że ujawnił się nawet u Františka Hrubína (1910-1971) - poety o dziesięć lat młodszego - w przypadku którego zdecydowanie nie można mówić o przejawach ekspresjonizmu. Przykład ten pokazuje, że wykonany przez Reynka przekład Trakla stał się jakoby oczywistym źródłem inspiracji. W pierwszym wierszu pierwszego tomiku Hrubína Zpíváno z dálky (1933) można znaleźć następujące wersy: "Jako chorá věc se leskne / luna v potocích" [„Jak chora rzecz lśni / księżyc w potokach"]. Wyrażenie "chorá věc" ["chora rzecz"] można znaleźć osobliwym tłumaczeniu wiersza Trakla U Mnišské hory w wykonaniu Reynka. U Trakla próżno szukać wyrażenia „chorá věc”, pojawia się tam „ein Krankes”, a więc "coś chorego". Sformułowania tego typu były u Trakla dość powszechne, a w języku czeskim można je oddać wyłącznie za pomocą opisu. Dziesięć lat później młody František Hrubín zainspirowany tym raczej eksperymentalnym tłumaczeniem wykorzystał zawarte w nim wyrażenie we własnym tekście. O zainteresowaniu Hrubína Traklem świadczy również późniejszy wiersz Čtenár u řeky - nad básněmi Georga Trakla z roku 1938.

Drugą fazę zainteresowania poezją Georga Trakla w poezji czeskiej, można zaobserwować w latach sześćdziesiątych dwudziestego wieku. Nie była wprawdzie tak wyraźna jak $w$ latach trzydziestych, ale ma interesujący związek $\mathrm{z}$ tłumaczeniem Trakla na język czeski. W roku 1965 w przekładzie Ludvíka Kundery wychodzi duży wybór wierszy Trakla pod tytułem Básně. Kundera, sam będąc poetą, zajmował się Traklem przez kilka dekad, a jego tłumaczenia wyszły w uaktualnionym wydaniu w roku 1995.

Od lat sześćdziesiątych Trakl oddziałuje przede wszystkim na Zbyňka Hejdę (ur. 1930), który należy do najwybitniejszych poetów w powojennej historii literatury czeskiej. W przypadku Hejdy wpływ ten jest niezaprzeczalny, poświadczony w literaturze przedmiotu, a ponadto umotywowany także tym, że poeta sam przetłumaczył i opublikował kilka wierszy Trakla. W poezji Hejdy słychać tony, które znaleźć można już u Františka Halasa czy Georga Trakla - jest to ponura, pozbawiona nadziei poezja przerażającego piękna, która ma tylko jeden temat główny: śmierć. Próżno jednakże u Hejdy szukać jakichkolwiek cytatów czy zapożyczeń z Trakla. Z pewnością również dlatego, że poezję Trakla odbierał z perspektywy dzielącego ich czasu i z zachowaniem stosownego dystansu. Hejda pozostał na swojej własnej poetyckiej ścieżce, mimo iż można powiedzieć, że w osobie Trakla odnalazł poetę bliźniaczego.

Na przykładzie stosunkowo krótkiego wiersza Před okny rudne listí vína z tomu Lady Felthamová (1992) widać zastosowane przez niego środki:

Před okny rudne listí vína.

Plot kolem zahrady se rozpadá.

Střechy stájí se propadly, 
rozpadá se zed' dvora.

Roubení studny sesuté.

Vzrostly kaštany na dvoře,

ty vzrostly!16

Tytuł wiersza, jest bardzo podobny do tytułu jednego z wierszy Trakla, co w przypadku Hejdy nie jest niczym niezwykłym. Chodzi mianowicie o utwór pod tytułem Im roten Laubwerk voll Guitarren, który znajduje się w pierwszym tomie poezji Trakla. Ponadto Hejda wykorzystuje kluczowy dla Trakla motyw rozkładu. W wierszu występuje rozpadający się płot wokół ogrodu, podwórze ze studnią oraz stajnia - przestrzenie i pojęcia z wierszy Trakla. Godne uwagi jest również to, że w wierszu Hejdy pojawiają się kasztany - albowiem to właśnie one, niejednokrotnie będąc $\mathrm{w}$ bezpośrednim związku $\mathrm{z}$ motywem studni czy też fontanny, stanowią tło znaczeniowe wierszy Trakla powstałych w Salzburgu - mieście jego dzieciństwa.

Pojawia się w tym miejscu pytanie, czy charakterystyczna dla Trakla „poetyka niewytłumaczalnej melancholii" odgrywa jakąś rolę w najnowszej czeskiej poezji, czy też jest to raczej zamknięty rozdział. Należy stwierdzić, iż dzieło Trakla jest wciąż tematem analiz literackich i naukowych (powstają nowe tłumaczenia, prace dyplomowe itp.), ale także źródłem poetyckiej inspiracji. Współcześni poeci jak np. Radek Fridrich, Bohdan Chlíbec, Jan Dadák, Jiří Staněk, Alena Nádvorníková czy też Viky Shock nadal wykorzystują traklowskie motywy. Szczególne miejsce w tym kontekście zajmuje dramat pod tytułem Trakl autorstwa Marka Horoščáka. Dramat powstał w roku 1998, a w roku 2002 został zrealizowany jako słuchowisko radiowe. Można zatem stwierdzić, iż „traklowska linia” jest w czeskiej poezji kontynuowana do dzisiaj i nie wydaje się, aby traciła na sile czy intensywności.

\section{Przełożyli z jezzyka czeskiego Izabela Szulc, Marcin Wagiel}

${ }_{16}$ Z. Hejda, Lady Felthamová, w: Básně. Praha 1996, s. 197. [Tłumaczenie filologiczne: „Przed oknami czerwienią się liście winorośli. / Płot wokół ogrodu się rozpada. / Dachy stajni zapadły się, / rozpada się mur podwórza. / Cembrowina studni zawalona. / Urosły kasztany na podwórzu, / ależ urosły!" (przyp. tłum.)] 